\title{
Productivity and Profitability of Kharif Rice Are Influenced by Crop Establishment Methods and Nitrogen Management in the Lateritic Belt of the Subtropical Region
}

\author{
Samata Mohanta ${ }^{1}\left(\mathbb{D}\right.$, Mahua Banerjee ${ }^{1}$, Ganesh Chandra Malik ${ }^{1}$, Tanmoy Shankar ${ }^{2}$, Sagar Maitra ${ }^{2} \mathbb{D}$, \\ Ismail Ahmed Ismail $^{3}\left(\mathbb{D}\right.$, Eldessoky S. Dessoky ${ }^{3, *(D)}$, Attia O. Attia ${ }^{3}$ and Akbar Hossain $4, * \mathbb{D}$ \\ 1 Department of Agronomy, Palli Siksha Bhavana, Visva-Bharati, Sriniketan 731204, India; \\ samata94@gmail.com (S.M.); mahua.banerjee@visva-bharati.ac.in (M.B.); \\ ganeshmalik_2004@rediffmail.com (G.C.M.) \\ 2 Department of Agronomy, Centurion University of Technology and Management, Odisha 761211, India; \\ tanmoy.shankar125@gmail.com (T.S.); sagar.maitra@cutm.ac.in (S.M.) \\ 3 Department of Biology, College of Science, Taif University, P.O. Box 11099, Taif 21944, Saudi Arabia; \\ i.ismail@tu.edu.sa (I.A.I.); ao.attia@tu.edu.sa (A.O.A.) \\ 4 Bangladesh Wheat and Maize Research Institute, Dinajpur 5200, Bangladesh \\ * Correspondence: es.dessouky@tu.edu.sa (E.S.D.); akbarhossainwrc@gmail.com (A.H.)
}

check for updates

Citation: Mohanta, S.; Banerjee, M.; Malik, G.C.; Shankar, T.; Maitra, S.; Ismail, I.A.; Dessoky, E.S.; Attia, A.O.; Hossain, A. Productivity and Profitability of Kharif Rice Are Influenced by Crop Establishment Methods and Nitrogen Management in the Lateritic Belt of the Subtropical Region. Agronomy 2021, 11, 1280. https://doi.org/10.3390/ agronomy 11071280

Academic Editors: Umberto Anastasi and Aurelio Scavo

Received: 18 May 2021

Accepted: 21 June 2021

Published: 24 June 2021

Publisher's Note: MDPI stays neutral with regard to jurisdictional claims in published maps and institutional affiliations.

Copyright: (c) 2021 by the authors. Licensee MDPI, Basel, Switzerland. This article is an open access article distributed under the terms and conditions of the Creative Commons Attribution (CC BY) license (https:// creativecommons.org/licenses/by/ $4.0 /)$.

\begin{abstract}
Nitrogen management is vital for economic and environmental sustainability. Asynchrony of fertilizer application with crop demand along various nitrogen losses in Eastern India leads to low fertilizer efficiency in Kharif rice. At the same time, direct-sowing is gaining popularity due to water and labor scarcity. In an experiment between 2017-2018 in West Bengal, India, the main plots represented establishment methods: conventional transplanting, TPR; direct-seeded rice, DSR; and drum seeded rice, DRR; while subplots represented nitrogen management options: farmer's practice (FP), the state-recommended (SR), nutrient expert-based (NE), Green seeker-based (GS) and LCC-based (LCC) in a split-plot design with three repetitions. Plant growth, productivity, and profitability were evaluated. All indicators of growth or production were affected by establishment methods and by N-management options. The yield enhancement of TPR and DSR over DRR was 21.1 and $16.8 \%$, respectively, while it was enhanced by $19.21,14.71,6.49$, and $2.52 \%$ by GS, NE, LCC, and $\mathrm{SR}$, respectively, over FP. The highest net return and return per rupee invested were recorded with DSR, while both GS and NE had better economics. The results suggest that the combination of DSR establishment with GS or NE requires further studies to find climate-smart management techniques in Kharif rice.
\end{abstract}

Keywords: direct seeding; drum seeder; establishment method; green seeker; growth and yield of rice; Kharif rice; LCC; nitrogen supplementation; nutrient expert; production cost

\section{Introduction}

Nitrogen $(\mathrm{N})$ is a yield-limiting nutrient for rice in India [1] and its efficient use is crucial for economic and environmental sustainability [2]. During the last five decades, the use of nitrogenous fertilizer in cropping systems has been increased [3], but a gradual reduction has also been noted in the crop yield response and fertilizer $\mathrm{N}$ use efficiency [4]. Inefficient utilization of nitrogen is considered to be the most critical one among various reasons for this low productivity. India is occupied by a large rice area, accounting for 43.7 Mha [5]. Around 65\% population of India depends on this cereal for their food security [6,7]. Hence, in India, food security is also synonymous with rice production security. In India, the crops which are usually sown at the beginning of the monsoon season around June and harvested in October-November are known as Kharif crops. The primary rice-growing season in India is the "Kharif". The Kharif rice (grown between June to November) in India accounts for $89 \%$ of the total rice area and $85 \%$ of total rice 
production at all Indian levels [8]. The largest Kharif rice area is in Eastern India, such as Odisha, West Bengal, Eastern Uttar Pradesh, Bihar, and Chhattisgarh. Rice productivity in Eastern India is lower (2.0 to 3.0 tonnes ha ${ }^{-1}$ ). The current production of Kharif rice is 97.10 Mt. By 2050, to feed the projected population of 1.65 billion, rice demand will increase to $197.40 \mathrm{Mt}$. If $40 \%$ increase in Kharif rice production alone in suitable areas, production can be increased to $104.55 \mathrm{Mt}$ [9].

In the early 1970s, Indian farmers were applying only $5 \%$ of the global fertilizer $\mathrm{N}$, but since 2015 it has increased to 16\% [10]. Blanket application of $\mathrm{N}$ fertilizer is the prime cause of low nitrogen use efficiency, increased cost of cultivation, and environmental degradation [11]. Due to substantial temporal and plot-to-plot unevenness in indigenous nitrogen supply of soil, broad-based $\mathrm{N}$ recommendations like state-recommended $\mathrm{N}$ application for rice cannot be helpful [12]. Real-time nitrogen management and site-specific nitrogen management (SSNM) are recent scientific approaches that ensure both increases in rice productivity and sustainability of the rice ecosystem. Nutrient expert is a nutrient estimation support tool that uses the concept of site-specific nutrient management and assists the extension functionaries in developing fertilizer recommendations customized to a specific field [13]. An optical sensor is an important tool of SSNM which uses crop biomass and nitrogen status of standing crop for fertilizer assessment [3].

While analyzing the cause of the low productivity of rice in Kharif conditions, it was observed that faulty rice establishment methods have a significant impact along with low nitrogen use efficiency. Successful cropping begins with good crop establishment. Over time, many rice establishment methods have been adopted depending on farmer's willingness, input and technology availability [14]. The benefits of the conventional transplanted rice in puddled conditions are added to nutrient availability, weed control, and reduced percolation loss of water because of puddling. On the other hand, continuous conventional puddling caused soil structure damage, hard-pan formation, soil permeability reduction, and decline in groundwater table [15]. "Direct seeded rice (DSR)" refers to the process of establishing a rice crop from seeds sown in the field rather than by transplanting seedlings from the nursery [16]. DSR is a possible establishment technique for future generations to combat issues, such as water scarcity, labor shortage, and greenhouse gas emission [17]. The constraint of labor requirement at the peak stage of cultural practices and the higher cost of cultivation can be redressed through direct seeding by sidestepping nursery raising, seedling uprooting, and transplanting. The availability of better weed management technologies, herbicides, and escalating labor costs are encouraging many farmers to move to direct seeding [18,19]. Many rice varieties were recognized in different countries of the world to cultivate under different establishment methods successfully $[20,21]$. Under DSR, prescriptive $\mathrm{N}$ fertilizer application in two or three equal splits followed by a corrective GS guided $\mathrm{N}$ fertilizer application at panicle initiation stage can improve $\mathrm{N}$ fertilizer use efficiency without any yield loss compared with the general recommendation in Northwestern India [22]. A higher benefit-cost ratio was obtained in DSR than the transplanted rice using a site-specific nitrogen management tool [23].

Previous researchers have conducted many experiments to determine the yield differences between DSR and TPR under various agroclimatic regions. Some studies have indicated that due to multiple issues with TPR and comparable yield associated with higher net return in DSR [24], it became popular among farmers. However, in contrast to this, many other studies reported yield loss and instability in DSR [25,26]. Experiments conducted before on climate-smart tools like nutrient expert-based or green seeker-based $\mathrm{N}$ management were mainly in the high $\mathrm{N}$ application area, focusing on saving $\mathrm{N}$ with equivalent yield [27,28]. However, in West Bengal, where the Kharif rice is predominant, farmers apply less $\mathrm{N}$ than optimal $[29,30]$. Therefore, along with climate-smart agriculture strategies, our research aimed to find out the most productive and profitable option of different management aspects suited for different rice establishment methods.

Based on the above considerations, our experiments were carried out to find the best $\mathrm{N}$ management options suitable under different establishment methods. Therefore, the 
objectives of this study were to (1) quantify the effect of establishment methods and $\mathrm{N}$ demand-supply on rice growth parameters, yield attributes, and yield and to (2) identify the most cost-effective establishment methods and N management tools; so that the most productive and profitable climate-smart strategies can be identified.

\section{Materials and Methods}

\subsection{Experimental Site}

The experimental site was at Chellakamarpada (Birbhum district) village in farmer's field, $\left(23^{\circ} 62^{\prime} \mathrm{N}\right.$ latitude and $\left.87^{\circ} 62^{\prime} \mathrm{E}\right)$ in sandy loam soil under the red and lateritic belt (Ultisols) of West Bengal, India. The climate is subtropical. The area falls in the region of the southwest monsoon, and rain generally starts in the third week of June and receives an annual rainfall of about $1190 \mathrm{~mm}$, of which about $80 \%$ is received a short duration of three months from mid-June to mid-September and the rest between October to May.

The crop received $1364.6 \mathrm{~mm}$ and $836.9 \mathrm{~mm}$ rainfall during the cropping period of 2017 and 2018. In 2017, crops received comparatively more rain during the crop establishment period that provided stress due to excess soil moisture. The meteorological data of the experimental site related to the weather conditions prevailing during crop seasons (from June 2017 to November 2017 in the first year) and (from June 2018 to November 2018 in the second year) with respect to rainfall, relative humidity, and temperature obtained from the agro-meteorological advisory services is presented in Figure 1.

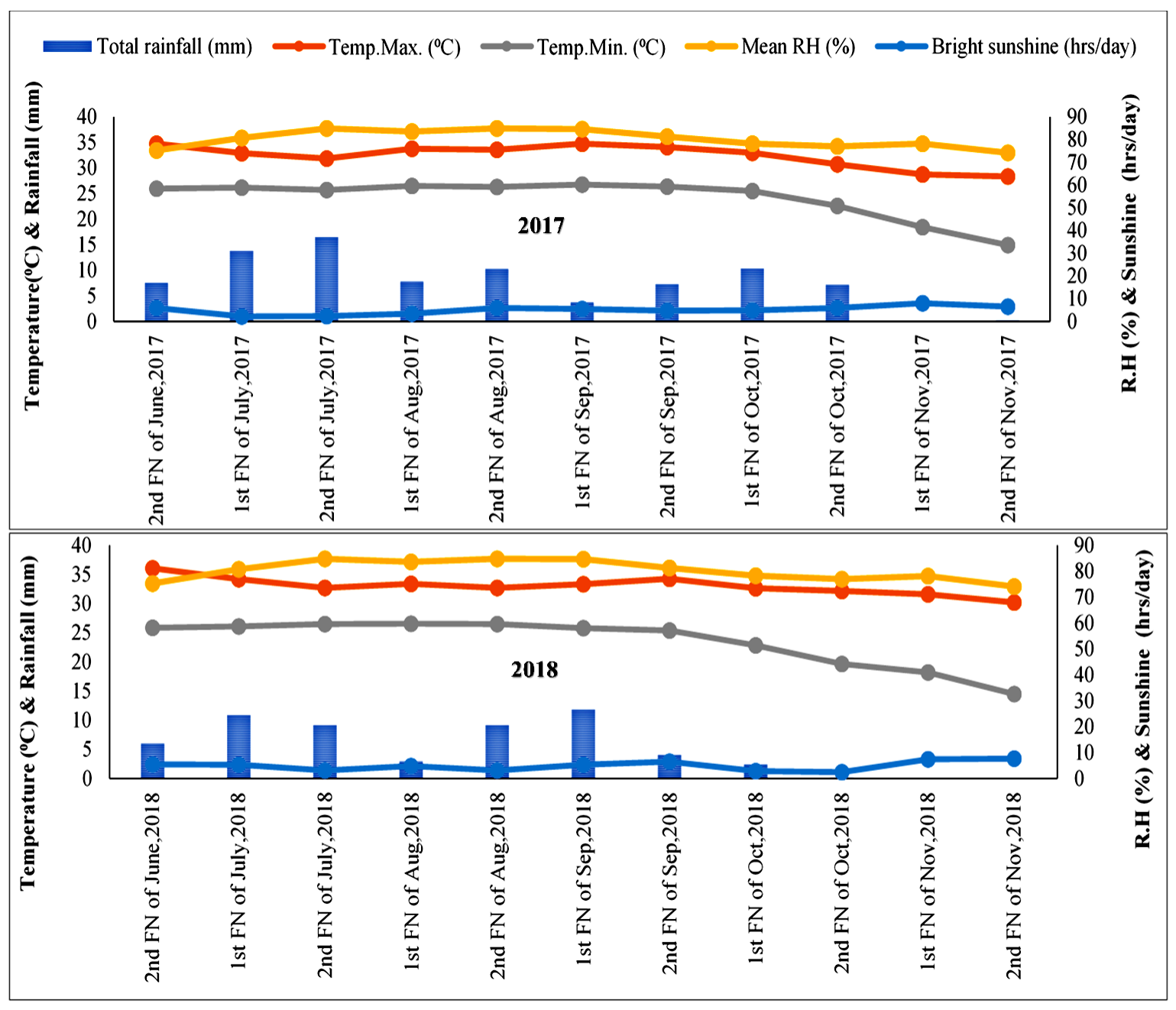

Figure 1. Fortnightly (FN) weather parameters in both crop seasons during 2017 and 2018. 
The initial soil textural class and fertility status like $\mathrm{pH}$ (6.06), organic carbon content $(0.36 \%)$, available $\mathrm{N}\left(185 \mathrm{~kg} \mathrm{ha}^{-1}\right)$, available $\mathrm{P}_{2} \mathrm{O}_{5}\left(26.6 \mathrm{~kg} \mathrm{ha}^{-1}\right)$, available $\mathrm{K}_{2} \mathrm{O}$ $\left(270.6 \mathrm{~kg} \mathrm{ha}^{-1}\right)$ were determined in the laboratory at the beginning of the experiment and presented in Table 1.

Table 1. Initial soil fertility status.

\begin{tabular}{ccc}
\hline Particulars & Value & Methods Followed \\
\hline Soil textural classes & Sandy loam & - \\
Sand (\%) & 72.6 & Hydrometer method [31] \\
Silt (\%) & 17.8 & Hydrometer method [31] \\
Clay (\%) & 9.6 & Hydrometer method [31] \\
Soil pH & 6.06 & Determined with the help of pH meter in 1:2.5 ratio of soil \\
& 0.22 & water suspension [32] \\
Electrical conductivity $(\mathrm{EC})\left(\mathrm{dS} \mathrm{m}^{-1}\right)$ & 0.36 & Using conductivity meter [32] \\
Organic carbon $(\%)$ & 185 & Volumetric weight combustion method [33] \\
Available nitrogen $\left(\mathrm{kg} \mathrm{ha}^{-1}\right)$ & 26.6 & Alkaline permanganate method [34] \\
Available phosphorus $\left(\mathrm{kg} \mathrm{ha}^{-1}\right)$ & 270.6 & Brays method No.1 [35] \\
Available potassium $\left(\mathrm{kg} \mathrm{ha}^{-1}\right)$ & & Flame photometer method [36]
\end{tabular}

\subsection{Experimental Treatments and Design}

The experiment was carried out for two consecutive years (2017 and 2018) in Kharif season. The research was conducted in a split-plot design comprising fifteen treatment combinations in $5 \mathrm{~m} \times 4 \mathrm{~m}$ net plot size and replicated thrice. Three crop establishment methods, i.e., "conventional transplanted rice (TPR)", "direct-seeded rice (DSR)", and "drum seeded rice (DRR)" were arranged in main plots and five nitrogen management options, i.e., "farmers' practice-based N management (FP)", "State recommended based N management (SR)", "Nutrient expert based N management (NE)", "Green seeker based N management (GS)" and "LCC based N management (LCC)" were taken as subplot treatments.

In this experiment, TPR was considered the standard practice among the establishment methods, which is being followed by the majority of the farmers in this area. The performance of the practices like DSR and DRR were compared with the standard practice. Similarly, in N-management, the improved $\mathrm{N}$ management options were compared with the farmer's practice.

\subsubsection{Farmer's Practice (FP)}

In the farmer's practice, fertilizer application was made as per the past 3 years' fertilizer application information of the experimental paddy plot. A questionnaire for past years' nutrient management was prepared, and information was collected from the farmer based on the questionnaire. A fertilizer dose of $68: 46: 37 \mathrm{~kg} \mathrm{ha}^{-1}$ of $\mathrm{N}: \mathrm{P}_{2} \mathrm{O}_{5}: \mathrm{K}_{2} \mathrm{O}$ was applied (Table 2). A total amount of phosphorus and potash were used as basal, and nitrogen was used in 3 splits.

\subsubsection{State Recommended Nitrogen Application (SR)}

In this treatment, fertilizer was applied as per the state recommended nutrient recommendations of West Bengal, i.e., 80:40:40 kg ha ${ }^{-1}$ of $\mathrm{N}: \mathrm{P}_{2} \mathrm{O}_{5}: \mathrm{K}_{2} \mathrm{O}$ was applied (Table 2) with three splittings of nitrogen and two splittings of potash at different growth stages of rice [37].

\subsubsection{Nutrient Expert Based Nitrogen Management (NE)}

The nutrient Expert fertilizer decision tool is developed by The International Plant Nutrition Institute (IPNI), in collaboration with IIRR and other national partners, which provides field-specific fertilizer recommendations. In this present study, through a prepared questionnaire, information such as farmer's current yield, characteristics of growing environment, soil fertility indicator (soil texture, color), crop sequence in the farmer's 
cropping pattern, crop residue management, and fertilizer and organic manure inputs were collected from the farmer [38]. An experimental field-specific fertilizer recommendation was developed using collected information as input of Nutrient Expert ${ }^{\circledR}$ for Rice-South Asia (India) software tool. Based on the developed Rice-Recommendation sheet of the experimental plot of Kamarpara village in May 2017, fertilizers were applied in both years of the experiment. The total dose of phosphoric fertilizer and potassic fertilizers were applied at the basal with three splittings of $\mathrm{N}$.

Table 2. Treatment wise $\mathrm{N}, \mathrm{P}_{2} \mathrm{O}_{5}$ and $\mathrm{K}_{2} \mathrm{O}$ application dose.

\begin{tabular}{|c|c|c|c|}
\hline Treatment & $\begin{array}{c}\text { Total N } \\
\text { Applied } \\
\left(\mathrm{kg} \mathrm{ha}^{-1}\right)\end{array}$ & $\begin{array}{c}\text { Total } \mathrm{P}_{2} \mathrm{O}_{5} \\
\text { Applied } \\
\left(\mathrm{kg} \mathrm{ha}^{-1}\right)\end{array}$ & $\begin{array}{c}\text { Total } \mathrm{K}_{2} \mathrm{O} \\
\text { Applied } \\
\left(\mathrm{kg} \mathrm{ha}^{-1}\right)\end{array}$ \\
\hline \multicolumn{4}{|c|}{ Farmer's practice (FP) } \\
\hline Conventional transplanted rice (TPR) & 68 & 46 & 37 \\
\hline Direct seeded rice (DSR) & 68 & 46 & 37 \\
\hline Drum seeded rice (DRR) & 68 & 46 & 37 \\
\hline \multicolumn{4}{|c|}{ State recommended based $\mathrm{N}$ management (SR) } \\
\hline Conventional transplanted rice (TPR) & 80 & 40 & 40 \\
\hline Direct seeded rice (DSR) & 80 & 40 & 40 \\
\hline Drum seeded rice (DRR) & 80 & 40 & 40 \\
\hline \multicolumn{4}{|c|}{ Nutrient expert based N management (NE) } \\
\hline Conventional transplanted rice (TPR) & 118 & 37 & 51 \\
\hline Direct seeded rice (DSR) & 118 & 37 & 51 \\
\hline Drum seeded rice (DRR) & 118 & 37 & 51 \\
\hline \multicolumn{4}{|c|}{ Green seeker based N management (GS) } \\
\hline Conventional transplanted rice (TPR) & 92.9 & 37 & 51 \\
\hline Direct seeded rice (DSR) & 95.3 & 37 & 51 \\
\hline Drum seeded rice (DRR) & 97.6 & 37 & 51 \\
\hline \multicolumn{4}{|c|}{ Leaf color chart based N management (LCC) } \\
\hline Conventional transplanted rice (TPR) & 79.6 & 40 & 40 \\
\hline Direct seeded rice (DSR) & 79.6 & 40 & 40 \\
\hline Drum seeded rice (DRR) & 79.6 & 40 & 40 \\
\hline
\end{tabular}

\subsubsection{Greenseeker Handheld Crop Sensor (GS)}

The Greenseeker handheld crop sensor (GS) was developed by Trimble agriculture as an active light source optical sensor used to measure plant biomass and displayed as NDVI (normalized difference vegetation index), which is used for $\mathrm{N}$ prescription recommendation [39]. In Green seeker-based nitrogen management, the basal dose and first top dressing of $\mathrm{N}$ fertilizer were applied as per nutrient expert-based nitrogen management, because of the interference of the exposed water background in reflectance measurements when the crop's canopy was not fully developed $[40,41]$. The second top dressing at the panicle initiation stage was done as per the estimated fertilizer rate. Total phosphoric fertilizer and potassic fertilizers were applied as basal.

\subsubsection{Leaf Color Chart (LCC)}

The leaf color chart used in the experiment was developed by the Central Rice Research Institute (CRRI), Cuttack, India, which is now renamed as ICAR-National Rice Research Institute (ICAR-NRRI). Two times nitrogen was top-dressed when LCC $<3^{*}$ with a basal dose of $26.5 \mathrm{~kg} \mathrm{~N} \mathrm{ha}^{-1}$ as per the recommendation of customized leaf color chart for nitrogen management in rice for different ecology [42]. Phosphorus and potassic fertilizers were applied as per the state recommended. 


\subsubsection{Direct Seeded Rice (DSR)}

In DSR, dry rice seeds were sown in line immediately after receiving favorable rain in moist but unsaturated soil before the onset of monsoon in both years of study.

\subsubsection{Drum Seeded Rice (DRR)}

In Drum seeded rice, direct seeding of pre-germinated paddy seeds was done through the fiber drums, which dispense seeds evenly in puddled and leveled fields.

\subsubsection{Conventional Transplanting (TPR)}

In the conventional transplanting (TPR) system, 21 days seedlings were transplanted manually in the puddled main field. Rice variety (HYV) "Pratikhya" was taken as an experimental crop variety. The dose of nutrients in all the treatment are presented in Table 2. In NE, attainable yield (Ya) was estimated through the Nutrient Expert fertilizer decision tool from maximum attainable yield (Ymax) for a geographic region or growing environment and farmers' actual nutrient-limited yield (Y) [38]. (Ya) was considered as target yield in both NE and GS. The amount of $\mathrm{N}$ fertilizer was calculated based on the grain yield targets $5 \mathrm{t} \mathrm{ha}^{-1}$ in NE and GS.

\subsection{Experimental Procedure}

In TPR, seedlings were grown in a wet nursery. Seeds were treated with Thiram 75\% WP @ $2 \mathrm{gm} \mathrm{kg}^{-1}$ of seed to prevent fungal diseases. For nursery raising, raised bed was laid out near the main field. In TPR and DRR methods of establishment, after the final puddling, planking and leveling were done. The beds were leveled vigilantly so that water would not stagnate at any place on the bed. Well-decomposed farmyard manure (FYM) was applied on the bed as per the local farmer's practice. In DRR, after puddling and land leveling, excess water was drained out the day before drum seeding. To achieve the successful establishment of DSR, the plot was ploughed two times with a disc harrow after tillage with a cultivator and followed by one planking to make ready a fine seedbed for seeding. Sowing in the nursery bed for seedling raising in TPR and sowing in the main field in DSR and DRR was done on the same day. Under TPR of transplanting, 21-22 days old seedlings were planted in a leveled field @ 2-3 seedlings/hill at a $20 \mathrm{~cm} \times 10 \mathrm{~cm}$ spacing. In DSR, treated dry seeds were sown in line @ 2-3 seeds/hill with the same spacing $(20 \mathrm{~cm} \times 10 \mathrm{~cm})$. In DRR, soaked and pre-germinated seeds were sown with an eight-row seed drum, in line with spacing $(20 \mathrm{~cm} \times 8 \mathrm{~cm})$. The seed drum was filled up to two-thirds of capacity. One of the funnel-shaped holes of the drum seeder was blocked by the cap to change the plant to plant spacing to $8 \mathrm{~cm}$. The crop was sown on 25 June 2017 and 16 June 2018.

The fertilizers were applied in the plots after layout as per treatments (Table 2). An N-rich strip was maintained within the field in a small area where enough fertilizer had been applied. This N-rich strip was taken as a reference area, and the normalized difference vegetation index (NDVI ref) value reading was recorded. By taking the NDVI ref, NDVI value of the experimental plot, and fertilizer estimation chart, the fertilizer rate was obtained for the GS.

\subsection{Measurements and Analytical Procedures}

\subsubsection{Growth and Yield Attributes}

The height of ten plants was recorded, and the mean value was calculated and expressed in centimeters $(\mathrm{cm})$. The number of tillers was counted by using $1 \mathrm{~m} \times 1 \mathrm{~m}$ quadrate from the second row. Leaving the first row from the border of each side of a plot, destructive samples were taken from the second row to record biometric observations, such as dry matter accumulation $\left(\mathrm{gm}^{-2}\right)$ and leaf area index (LAI). To determine the dry matter accumulation, rice plants were cut at ground level from each plot randomly as destructive samples. For leaf area, the representative green leaves were taken randomly from destructive samples, and their areas were recorded by leaf area meter. The destructive 
samples were dried in a hot air oven at $80^{\circ} \mathrm{C}$ for $10 \mathrm{~h}$ until constant weights were obtained as per the standard procedure [43]. The recorded dry weights of plants and leaves were used to calculate dry matter accumulation and leaf area index. The ratio of the recorded leaf area and dry weight of these leaves was used to measure the leaf area indices, since LAI is the area of leaf surface per unit of the land surface [44,45] (Equation (1)).

$$
\text { Leaf area index }=\frac{\text { Leaf area }}{\text { ground area }}
$$

Five plants were harvested, dried and their yield attributes were recorded.

\subsubsection{Yield}

The grain yield obtained from each treatment in the net plot area was sundried, threshed, winnowed, and cleaned. After that, the weight of the grains per net plot was recorded at $14 \%$ moisture with the help of electronic balance. Each treatment's grain yield per hectare was calculated from the net plot yield and expressed in $\mathrm{kg} \mathrm{ha}^{-1}$.

\subsubsection{Economics}

The total cost of production $\mathrm{ha}^{-1}$ for each treatment was calculated based on the current market rate of inputs like seed, fertilizer, herbicide, pesticide. Hired machinery costs for land preparation, sowing, and threshing, labor cost, irrigation costs were were also added to production costs. Gross return was calculated based on the products' prevailing market price, and accordingly, net return was calculated. Dividing this net return by the cost of cultivation, we obtained the return per rupee invested. Based on the return per rupee (Indian currency) invested, the most beneficial treatment for the crop sequence was determined (Equation (2)).

$$
\text { Return per rupee invested }=\frac{\text { Net return }}{\text { cost of cultivation }}
$$

\subsection{Calculations and Statistical Analysis}

The experimental data were analyzed statistically by using analysis of variance (ANOVA). The standard error of means (SEm \pm ) and the critical difference at a $5 \%$ probability level of significance (CD, $p \leq 0.05$ ) [46]. Excel software (Microsoft Office Home and Student version 2019-en-us, Microsoft Inc., Redmond, Washington, DC, (USA) was used for statistical analysis and drawing graphs and figures.

\section{Results}

\subsection{Growth Parameter}

The pooled data for two years of study are presented in Table 3 to show the impact of establishment methods and nitrogen management on plant height $(\mathrm{cm})$ at harvest and tillers $\mathrm{m}^{-2}$ at the maximum tillering stage of the "Pratikhya" variety of rice grown in Kharif conditions. The observations showed that establishment methods influenced the plant height of rice in 2018, and DSR recorded significantly taller plant height than TPR and DRR at harvest. (Table 3). Pooled data for two years did not show any significant impact in increasing plant height among different establishment methods. NE and GS exhibited the highest plant height among different $\mathrm{N}$ management treatments, while LCC, SR, and FP presented significantly lower plant height than NE. LCC showed significantly higher plant height than FP (Table 3).

The data on the number of tillers per unit area $\left(\mathrm{m}^{-2}\right)$ revealed that the crop establishment methods and nitrogen management influenced the tillers production in "Pratikhya" Kharif rice in both the years of experimentation (Table 3). The treatment TPR being statistically on par with DSR produced a significantly greater number of tillers than the DRR method of rice establishment during both years. Pooled data for two years also showed a similar trend. Among the $\mathrm{N}$ management options, FP resulted in significantly lowest 
tillers production of "Pratikhya" Kharif rice over other treatments in the study. The data of individual years and pooled data showed that GS and NE treatments remained statistically on par in production of the number of tillers per unit area at 75 DAS. These two treatments were significantly superior to other treatments.

Table 3. Influence of crop establishment method and nitrogen management on plant height $(\mathrm{cm})$ and the number of tillers $\mathrm{m}^{-2}$ of "Pratikhya" Kharif rice variety.

\begin{tabular}{|c|c|c|c|c|c|c|}
\hline \multirow{3}{*}{ Treatments } & \multicolumn{3}{|c|}{ Plant Height (cm) } & \multicolumn{3}{|c|}{ Number of Tillers $\mathrm{m}^{-2}$} \\
\hline & \multicolumn{3}{|c|}{ At harvest } & \multicolumn{3}{|c|}{ At 75 DAS } \\
\hline & 2017 & 2018 & Pooled & 2017 & 2018 & Pooled \\
\hline \multicolumn{7}{|c|}{ Establishment method } \\
\hline TPR & $117.7^{\mathrm{a}}$ & $102.1^{\mathrm{b}}$ & 109.9 & $350.9^{a}$ & $343.5^{a}$ & $347.2^{\mathrm{a}}$ \\
\hline DSR & $111.8^{\mathrm{a}}$ & $118.6^{\mathrm{a}}$ & 115.2 & $321.2^{b}$ & $329.4^{\mathrm{a}}$ & $325.9^{a b}$ \\
\hline DRR & $114.4^{\mathrm{a}}$ & $107.0^{\mathrm{b}}$ & 110.6 & $299.5^{b}$ & $306.5^{b}$ & $300.0^{b}$ \\
\hline $\mathrm{SEm} \pm$ & 2.0 & 2.0 & 1.4 & 7.1 & 6.9 & 7.0 \\
\hline $\mathrm{CD}$ at $5 \%$ & NS & 7.9 & NS & 27.8 & 27.2 & 27.7 \\
\hline \multicolumn{7}{|c|}{ Nitrogen management } \\
\hline $\mathrm{FP}$ & $107.0^{\mathrm{c}}$ & $101.8^{\mathrm{c}}$ & $104.4^{\mathrm{d}}$ & $285.4^{\mathrm{c}}$ & $281.4^{\mathrm{c}}$ & $283.7^{\mathrm{c}}$ \\
\hline SR & $111.9 \mathrm{bc}$ & $104.4^{\mathrm{c}}$ & $108.2^{c}$ & $306.8^{b c}$ & $312.6^{\mathrm{b}}$ & $308.6^{b}$ \\
\hline $\mathrm{NE}$ & $122.2^{\mathrm{a}}$ & $119.2^{\mathrm{a}}$ & $120.7^{\mathrm{a}}$ & $347.2^{\mathrm{a}}$ & $360.9^{a}$ & $353.2^{\mathrm{a}}$ \\
\hline GS & $118.4^{\mathrm{ab}}$ & $113.0^{\mathrm{ab}}$ & $115.7^{b}$ & $364.7^{\mathrm{a}}$ & $357.0^{\mathrm{a}}$ & $360.0^{a}$ \\
\hline LCC & $113.7^{\mathrm{abc}}$ & $107.7^{b c}$ & $110.7^{\mathrm{c}}$ & $315.2^{b}$ & $320.4^{b}$ & $316.3^{b}$ \\
\hline $\mathrm{SEm} \pm$ & 3.2 & 2.6 & 2.1 & 8.2 & 8.8 & 8.2 \\
\hline $\mathrm{CD}$ at $5 \%$ & 9.4 & 7.7 & 5.9 & 23.9 & 25.8 & 23.9 \\
\hline teraction effect & NS & NS & NS & NS & NS & NS \\
\hline
\end{tabular}

Different lowercase letters within the continuous columns are significantly different at $5 \%$ level of probability in Duncan's multiple ranges test (DMRT). Note: Conventional transplanting (TPR), direct-seeded rice (DSR) and drum seeded rice (DRR); farmer's practice (FP), the state recommended (SR), nutrient expert based (NE), Green seeker based (GS), leaf color chart (LCC) and non-significant (NS).

Year-wise and pooled data on dry matter accumulation were presented in Table 4 indicated that nitrogen management and establishment methods significantly influenced dry matter accumulation $\left(\mathrm{gm}^{-2}\right)$ of "Pratikhya" Kharif rice. Among the different rice establishment methods, TPR showed its significant superiority over other two methods, namely DSR and DRR in dry matter production in the harvest stage of "Pratikhya" kharif rice in 2017; but in 2018, DSR resulted in significantly more dry matter accumulation than TPR and DRR. Based on pooled data, DSR and TPR recorded significantly more dry matter production $\left(\mathrm{gm}^{-2}\right)$ than DRR. In $\mathrm{N}$ management, a similar trend was noted in individual years and the pooled data (Table 4 ). The N management treatments, such as NE and GS, resulted in significantly more dry matter accumulation over other treatments.

Data on leaf area index (LAI) revealed that TPR was statistically on par with DSR, registered significantly higher values of LAI at 95 DAS than DRR rice in 2017 and pooled data (Table 4). Among different N management treatments, NE registered higher values in LAI during both the years, and GS closely followed it; however, these two treatments were statistically on par as reflected in individual years' data. But pooled data registered the significant superiority of the treatment NE over other treatments. N management in FP resulted in the least values of LAI of "Pratikhya" Kharif rice at 95 DAS. 
Table 4. Influence of crop establishment method and nitrogen management on dry matter accumulation $\left(\mathrm{gm}^{-2}\right)$ and leaf area index of "Pratikhya" Kharif rice variety.

\begin{tabular}{|c|c|c|c|c|c|c|}
\hline \multirow{3}{*}{ Treatments } & \multicolumn{3}{|c|}{ Dry Matter Accumulation $\left(\mathrm{gm}^{-2}\right)$} & \multicolumn{3}{|c|}{ Leaf Area Index (LAI) } \\
\hline & \multicolumn{3}{|c|}{ at Harvest } & \multicolumn{3}{|c|}{ at 95 DAS } \\
\hline & 2017 & 2018 & Pooled & 2017 & 2018 & Pooled \\
\hline \multicolumn{7}{|c|}{ Establishment method } \\
\hline TPR & $1274.1^{\mathrm{a}}$ & $1129.2^{b}$ & $1201.7^{\mathrm{a}}$ & $4.97^{\mathrm{a}}$ & 4.52 & $4.74^{\mathrm{a}}$ \\
\hline DSR & $1020.8^{b}$ & $1462.4^{\mathrm{a}}$ & $1241.6^{\mathrm{a}}$ & $4.70^{\mathrm{a}}$ & 4.39 & $4.54^{\mathrm{a}}$ \\
\hline DRR & $980.9^{b}$ & $1093.9^{b}$ & $1037.4^{b}$ & $4.12^{\mathrm{b}}$ & 4.24 & $4.18^{\mathrm{b}}$ \\
\hline $\mathrm{SEm} \pm$ & 22.1 & 45.9 & 29.6 & 0.08 & 0.13 & 0.08 \\
\hline $\mathrm{CD}$ at $5 \%$ & 87.0 & 180.3 & 116.4 & 0.33 & NS & 0.26 \\
\hline \multicolumn{7}{|c|}{ Nitrogen management } \\
\hline $\mathrm{FP}$ & $948.2^{c}$ & $1051.1^{\mathrm{c}}$ & $999.6^{\mathrm{b}}$ & $4.22^{c}$ & $3.97^{\mathrm{c}}$ & $4.09^{d}$ \\
\hline SR & $1022.6^{c}$ & $1163.0 \mathrm{bc}$ & $1092.8^{b}$ & $4.30^{c}$ & $4.23 \mathrm{bc}$ & $4.27^{\mathrm{d}}$ \\
\hline $\mathrm{NE}$ & $1278.2^{\mathrm{a}}$ & $1428.5^{\mathrm{a}}$ & $1353.4^{\mathrm{a}}$ & $5.15^{\mathrm{a}}$ & $4.74^{\mathrm{a}}$ & $4.95^{\mathrm{a}}$ \\
\hline GS & $1169.9^{b}$ & $1315.2^{a b}$ & $1242.5^{\mathrm{a}}$ & $4.82^{\mathrm{ab}}$ & $4.53^{\mathrm{ab}}$ & $4.67^{b}$ \\
\hline LCC & $1040.9^{c}$ & $1184.8^{b c}$ & $1112.9^{b}$ & $4.49^{b c}$ & $4.45^{\mathrm{ab}}$ & $4.47^{\mathrm{c}}$ \\
\hline SEm \pm & 35.6 & 77.3 & 43.2 & 0.12 & 0.12 & 0.08 \\
\hline $\mathrm{CD}$ at $5 \%$ & 103.9 & 225.5 & 126.2 & 0.34 & 0.35 & 0.24 \\
\hline teraction effect & NS & NS & NS & NS & NS & NS \\
\hline
\end{tabular}

Different lowercase letters within the continuous columns are significantly different at $5 \%$ level of probability in Duncan's multiple ranges test (DMRT). Note: Conventional transplanting (TPR), direct-seeded rice (DSR) and drum seeded rice (DRR); farmer's practice (FP), the state recommended (SR), nutrient expert based (NE), Green seeker based (GS), leaf color chart (LCC) and non-significant (NS).

\subsection{Grain Yield and Yield Attributes}

The individual years and pooled data on yield attributes of "Pratikhya" rice under Kharif season indicated that crop establishment methods and nitrogen management influenced the yield parameters and yield (Table 5; Figures 2 and 3). The effect of treatments on yield attributes and yield are narrated in the following segment. The present study revealed that the treatment TPR being statistically on par with DSR registered significantly higher effective tillers $\mathrm{m}^{-2}$ than the DRR method of crop establishment as noted in individual years and pooled data. $\mathrm{N}$ management treatments also significantly affected effective tillers. GS-based N management being statistically on par with NE-based nutrient management resulted in significantly superior to other treatments. FP-based $\mathrm{N}$ management showed poor performance in comparison to others. The pooled data revealed that SR, LCC, NE, and GS increased effective tillers over farmer's practice by $4.36,7.8,16.40$, and $22.88 \%$, respectively.

The number of filled grains panicle ${ }^{-1}$ is an important yield attributing character influencing the productivity of "Pratikhya" Kharif rice. The results revealed that the conventional TPR resulted in significantly higher filled grains panicle ${ }^{-1}$ than the other two methods, viz, DSR and DRR in "Pratikhya" under Kharif 2017 (Table 5). DSR and DRR remained statistically on par in an expression of filled grains panicle ${ }^{-1}$. Pooled data also showed a similar trend as noted in 2017. N management treatments influenced filled grains panicle ${ }^{-1}$ of "Pratikhya" Kharif rice. The treatment GS recorded significantly higher filled grains panicle ${ }^{-1}$ than other treatments, namely, FP, SR, LCC, and NE-based nitrogen management. 
Table 5. Influence of crop establishment methods and nitrogen management on yield attributes of "Pratikhya" Kharif rice variety.

\begin{tabular}{|c|c|c|c|c|c|c|c|c|c|}
\hline \multirow{2}{*}{ Treatments } & \multicolumn{3}{|c|}{ Effective Tillers $\mathrm{m}^{-2}$} & \multicolumn{3}{|c|}{ Filled Grains/Panicle } & \multicolumn{3}{|c|}{ Test Weight (g) } \\
\hline & 2017 & 2018 & Pooled & 2017 & 2018 & Pooled & 2017 & 2018 & Pooled \\
\hline \multicolumn{10}{|c|}{ Establishment method } \\
\hline TPR & $287.6^{\mathrm{a}}$ & $277.2^{\mathrm{a}}$ & $282.4^{\mathrm{a}}$ & $104.2^{\mathrm{a}}$ & $96.8^{a}$ & $100.5^{\mathrm{a}}$ & 26.4 & 25.8 & 26.1 \\
\hline DSR & $279.7^{\mathrm{a}}$ & $263.4^{\mathrm{ab}}$ & $271.5^{\mathrm{a}}$ & $86.2^{b}$ & $93.3^{b}$ & $89.7^{b}$ & 25.7 & 26.0 & 25.9 \\
\hline DRR & $245.2^{b}$ & $240.6^{\mathrm{b}}$ & $242.9^{b}$ & $83.1^{\mathrm{b}}$ & $86.6^{\mathrm{b}}$ & $84.8^{\mathrm{b}}$ & 25.0 & 24.9 & 25.0 \\
\hline SEm \pm & 7.9 & 7.0 & 5.2 & 3.3 & 2.8 & 2.2 & 0.4 & 0.5 & 0.3 \\
\hline $\mathrm{CD}$ at $5 \%$ & 30.8 & 27.3 & 17.1 & 13.0 & NS & 7.0 & NS & NS & NS \\
\hline \multicolumn{10}{|c|}{ Nitrogen Management } \\
\hline FP & $231.9^{c}$ & $249.7^{b}$ & $240.8^{c}$ & $79.2^{b}$ & $82.5^{c}$ & $80.9^{d}$ & 23.6 & 24.7 & 24.1 \\
\hline SR & $249.4^{b c}$ & $253.1^{b}$ & $251.3^{c}$ & $86.2^{b}$ & $84.3^{c}$ & $85.3^{c}$ & 25.2 & 25.5 & 25.3 \\
\hline NE & $295.4^{\mathrm{a}}$ & $265.2^{a b}$ & $280.3^{\mathrm{ab}}$ & $97.4^{\mathrm{a}}$ & $97.5^{b}$ & $97.5^{\mathrm{b}}$ & 26.4 & 26.6 & 26.5 \\
\hline GS & $313.9^{\mathrm{a}}$ & $277.9^{a}$ & $295.9^{a}$ & $106.1^{\mathrm{a}}$ & $107.1^{\mathrm{a}}$ & $106.6^{\mathrm{a}}$ & 26.4 & 25.6 & 26.0 \\
\hline LCC & $263.4^{b}$ & $256.1^{\mathrm{b}}$ & $259.8^{b c}$ & $86.9^{b}$ & $89.6^{b c}$ & $88.3^{c}$ & 27.0 & 25.6 & 26.3 \\
\hline SEm \pm & 9.3 & 6.6 & 5.7 & 3.2 & 3.1 & 2.2 & 0.9 & 0.7 & 0.6 \\
\hline $\mathrm{CD}$ at $5 \%$ & 27.0 & 19.2 & 16.1 & 9.2 & 9.2 & 6.3 & NS & NS & NS \\
\hline Interaction effect & NS & & & NS & & & NS & & NS \\
\hline
\end{tabular}

Different lowercase letters within the continuous columns are significantly different at $5 \%$ level of probability in Duncan's multiple ranges test (DMRT). Note: Conventional transplanting (TPR), direct-seeded rice (DSR) and drum seeded rice (DRR); farmer's practice (FP), the state recommended (SR), nutrient expert based (NE), Green seeker based (GS), leaf color chart (LCC) and non-significant (NS).

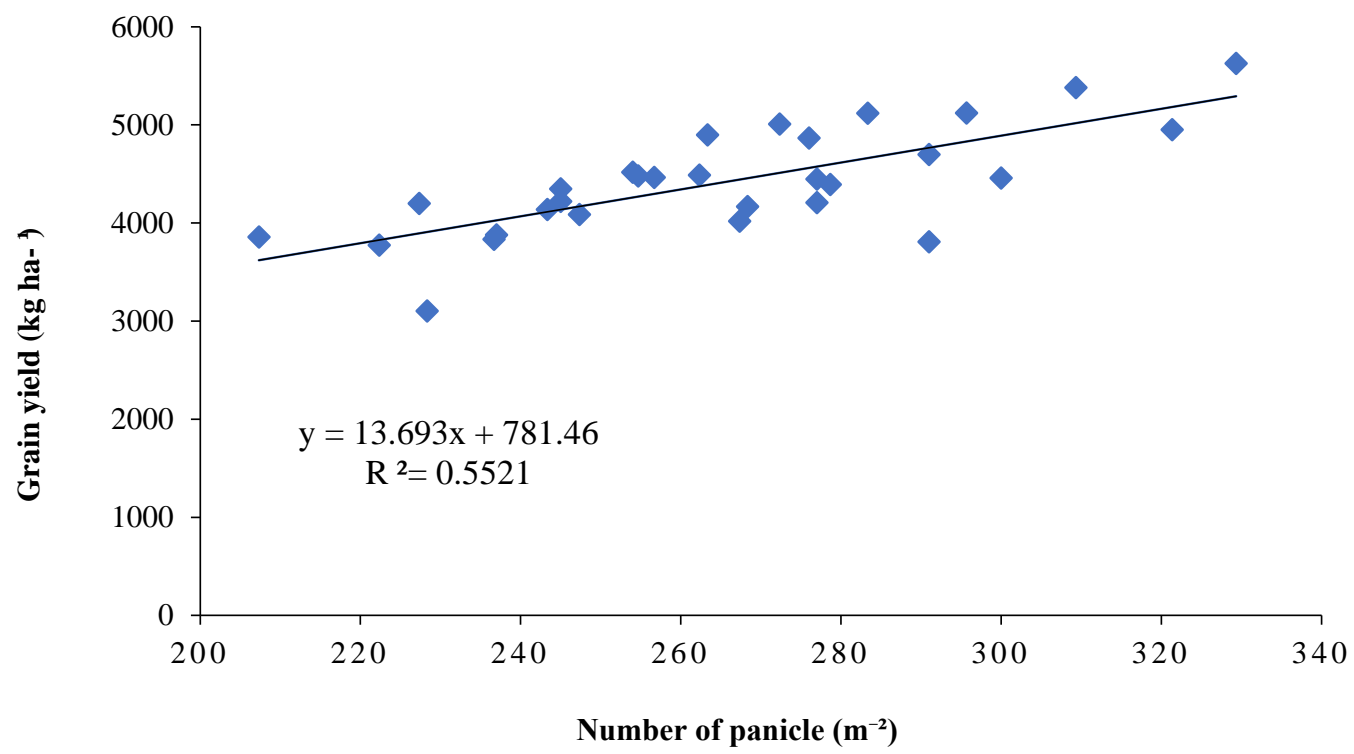

Figure 2. Linear regression between yield $\left(\mathrm{kg} \mathrm{ha}^{-1}\right)$ and panicles $\left(\mathrm{m}^{-2}\right)$ of "Pratikhya" Kharif rice variety.

Grain and straw yields of "Pratikhya" Kharif rice were influenced by the crop establishment method and nitrogen management. The result of the treatments on grain and straw yield of rice in the present experiment was narrated in the following segment. During both years, grain yield was influenced by rice establishment methods (Table 6). In 2017, the TPR method of crop establishment produced more grain yield, and during 2018, DSR yielded more rice grains, but there was no significant difference between TPR and DSR during both years. TPR and DSR produced significantly higher grain yields than DRR (Table 6). 


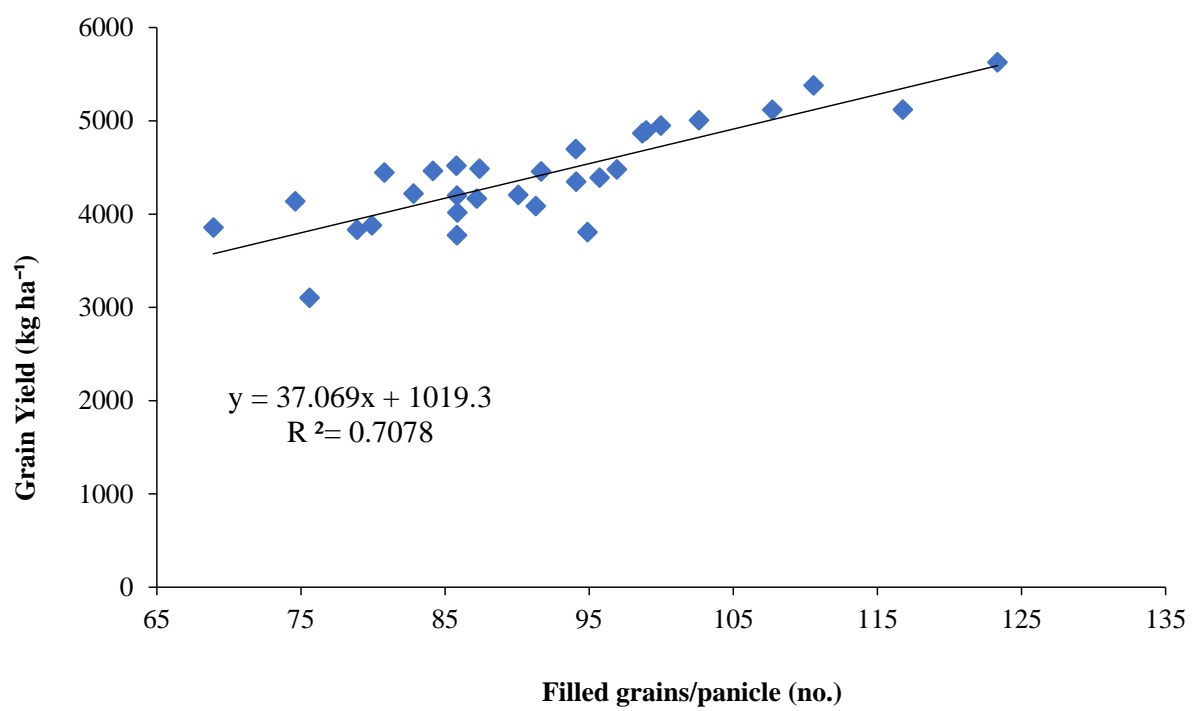

Figure 3. Linear regression between yield $\left(\mathrm{kg} \mathrm{ha}^{-1}\right)$ and filled grain/panicle (no.) of "Pratikhya" Kharif rice variety.

The pooled data showed a similar trend as noted in 2017. Among the $\mathrm{N}$ management treatments, GS being statistically on par with NE, registered a significantly higher grain yield than other treatments, such as FP, SR, and LCC, as noted in individual years and pooled data (Table 6). The pooled data showed that yield enhancement in GS and NE was $19.2 \%$ and $14.7 \%$ over FP. LCC recorded a significantly lower yield than GS and NE. Crop establishment methods impacted on straw yield of "Pratikhya" under Kharif rice (Table 6). The maximum straw yield was recorded with TPR during both years, and pooled data also showed a similar trend. However, data of 2017 and pooled data showed that TPR produced significantly higher straw yield than the other two establishment methods, namely, DSR and DRR. But in 2018, TPR being statistically on par with DSR, produced significantly more straw yield than DRR. Among N management treatments, NE resulted in the maximum straw yield. In 2017, NE being statistically on par with GS and LCC, produced significantly higher straw yield than FP and SR. But the data of 2018 and pooled data revealed that NE being statistically on par with GS, had significantly more straw yield than other treatments, namely, FP, SR, and LCC. The percentage increase in straw yield of NE, GS, LCC, and SR over FP was 19.19, 14.94, 10.40, and 6.08\%, respectively.

\subsection{Economics}

Based on pooled data (Table 7), the result showed that the maximum gross return per hectare (Rs. 110,121 ha-1) was recorded with TPR, but no significant variation was observed between TPR and DSR. The conventional transplanting fetched Rs. $5122 \mathrm{ha}^{-1}$ higher gross return than direct-seeded rice and Rs. 19,249 ha $^{-1}$ higher gross return than drum seeded rice (Table 7).

But DSR recorded the highest net return per hectare (Rs. $63,726 \mathrm{ha}^{-1}$ ) due to less cost of cultivation involved in DSR in puddling and transplanting operation. DSR fetched more net return of (+ Rs. $1457 \mathrm{ha}^{-1}$ ) than TPR, but there was no significant variation in net return between TPR and DSR. The maximum return per rupee invested (Rs. 2.54) was recorded with DSR, and it was significantly higher than TPR (Rs. 2.30) (Table 7). GS fetched a more gross return of Rs. $17,118 \mathrm{ha}^{-1}$, Rs. $14,027 \mathrm{ha}^{-1}$, Rs. $10,241 \mathrm{ha}^{-1}$, and Rs. $2426 \mathrm{ha}^{-1}$ compared to FP, SR, LCC, and NE, respectively (Table 7). The same trend was observed with net return ha ${ }^{-1}$. GS fetched more net return of (+ Rs. 16,798 ha $\left.{ }^{-1}\right),\left(+\right.$ Rs. 13,725 ha $\left.{ }^{-1}\right)$, (+Rs. $9932 \mathrm{ha}^{-1}$ ) and (+Rs. $\left.2836 \mathrm{ha}^{-1}\right)$ than FP, SR, LCC, and NE, respectively. There was no significant difference in gross return and net return between GS and NE. The highest return per rupee invested (Rs. 2.52) was recorded in GS, which was statistically on par with NE (Rs. 2.44) (Table 7). 
Table 6. Influence of crop establishment methods and nitrogen management on yield of "Pratikhya" Kharif rice variety.

\begin{tabular}{|c|c|c|c|c|c|c|}
\hline \multirow{2}{*}{ Treatments } & \multicolumn{3}{|c|}{ Grain Yield (kg ha) } & \multicolumn{3}{|c|}{ Straw Yield (kg ha) } \\
\hline & 2017 & 2018 & Pooled & 2017 & 2018 & Pooled \\
\hline \multicolumn{7}{|c|}{ Establishment method } \\
\hline TPR & $4990^{a}$ & $4513^{a}$ & $4751^{a}$ & $6359^{a}$ & $5940^{a}$ & $6150^{a}$ \\
\hline DSR & $4491^{\mathrm{a}}$ & $4671^{a}$ & $4581^{a}$ & $5676^{b}$ & $5594^{a}$ & $5635^{a}$ \\
\hline DRR & $3750^{b}$ & $4095^{b}$ & $3923^{b}$ & $5130^{c}$ & $5002^{b}$ & $5066^{b}$ \\
\hline $\mathrm{SEm} \pm$ & 136 & 99 & 84 & 138 & 126 & 93 \\
\hline $\mathrm{CD}$ at $5 \%$ & 534.3 & 390.1 & 274.8 & 542.7 & 492.7 & 304.4 \\
\hline \multicolumn{7}{|c|}{ Nitrogen Management } \\
\hline $\mathrm{FP}$ & $4114^{b}$ & $4024^{c}$ & $4069^{c}$ & $5151^{c}$ & $5050^{d}$ & $5100^{d}$ \\
\hline SR & $4155^{b}$ & $4188^{b c}$ & $4172 \mathrm{bc}$ & $5543^{b c}$ & $5278^{\mathrm{cd}}$ & $5411^{c}$ \\
\hline $\mathrm{NE}$ & $4682^{a}$ & $4653^{a b}$ & $4668^{a}$ & $6191^{a}$ & $5967^{\mathrm{a}}$ & $6079^{a}$ \\
\hline GS & $4795^{\mathrm{a}}$ & $4906^{a}$ & $4851^{a}$ & $5981^{a b}$ & $5744^{\mathrm{ab}}$ & $5862^{a b}$ \\
\hline LCC & $4306^{a b}$ & $4360 \mathrm{abc}$ & $4333^{b}$ & $5742^{a b}$ & $5520^{b c}$ & $5631^{b c}$ \\
\hline SEm \pm & 161 & 186 & 123 & 183 & 115 & 108 \\
\hline $\mathrm{CD}$ at $5 \%$ & 470.8 & 541.9 & 349.7 & 533.1 & 336.3 & 307.0 \\
\hline Interaction effect & NS & NS & NS & NS & NS & NS \\
\hline
\end{tabular}

Different lowercase letters within the continuous columns are significantly different at $5 \%$ level of probability in Duncan's multiple ranges test (DMRT). Note: Conventional transplanting (TPR), direct-seeded rice (DSR) and drum seeded rice (DRR); farmer's practice (FP), the state recommended (SR), nutrient expert based (NE), Green seeker based (GS), leaf color chart (LCC) and non-significant (NS).

Table 7. Influence of crop establishment methods and nitrogen management on the economics of "Pratikhya" Kharif rice variety.

\begin{tabular}{|c|c|c|c|c|c|c|c|c|c|}
\hline \multirow{2}{*}{ Treatments } & \multicolumn{3}{|c|}{ Gross Return (Rs/ha) } & \multicolumn{3}{|c|}{ Net Return (Rs/ha) } & \multicolumn{3}{|c|}{$\begin{array}{l}\text { Return per Rupee Invested } \\
\text { (Rs/ha) }\end{array}$} \\
\hline & 2017 & 2018 & Pooled & 2017 & 2018 & Pooled & 2017 & 2018 & Pooled \\
\hline \multicolumn{10}{|c|}{ Establishment method } \\
\hline TPR & $115,257^{\mathrm{a}}$ & $104,985^{a}$ & $110,121^{\mathrm{a}}$ & $67,709^{a}$ & $56,830^{b}$ & $62,269^{a}$ & $2.42^{\mathrm{a}}$ & $2.18^{b}$ & $2.30^{b}$ \\
\hline DSR & $103,548^{b}$ & $106,450^{a}$ & $104,999^{a}$ & $62,549^{a}$ & $64,902^{a}$ & $63,726^{a}$ & $2.53^{\mathrm{a}}$ & $2.56^{\mathrm{a}}$ & $2.54^{\mathrm{a}}$ \\
\hline DRR & $88,020^{\mathrm{c}}$ & $93,724^{b}$ & $90,872^{b}$ & $46,007^{b}$ & $51,111^{b}$ & $48,559^{b}$ & $2.09^{b}$ & $2.20^{\mathrm{b}}$ & $2.15^{\mathrm{c}}$ \\
\hline $\mathrm{SEm} \pm$ & 2947 & 1919 & 1758 & 2947 & 1919 & 1758 & 0.07 & 0.05 & 0.04 \\
\hline $\mathrm{CD}$ at $5 \%$ & 11,567 & 7534 & 5733 & 11,567 & 7534 & 5733 & 0.27 & 0.18 & 0.14 \\
\hline \multicolumn{10}{|c|}{ Nitrogen management } \\
\hline $\mathrm{FP}$ & $94,656^{c}$ & $92,627^{b}$ & $93,642^{c}$ & $51,359^{b}$ & $48,730^{\mathrm{c}}$ & $50,045^{c}$ & $2.19^{b}$ & $2.12^{\mathrm{c}}$ & $2.16^{\mathrm{c}}$ \\
\hline SR & $96,965^{c}$ & $96,501^{b}$ & 96,733 bc & $53,651^{b}$ & $52,586^{\mathrm{bc}}$ & $53,118^{\text {bc }}$ & $2.23^{b}$ & $2.21 \mathrm{bc}$ & $2.22^{b c}$ \\
\hline $\mathrm{NE}$ & $109,036^{a b}$ & $107,632^{a}$ & $108,334^{a}$ & $65,009^{a}$ & $63,004^{a b}$ & $64,007^{\mathrm{a}}$ & $2.47^{\mathrm{a}}$ & $2.42^{\mathrm{ab}}$ & $2.44^{\mathrm{a}}$ \\
\hline GS & $110,236^{\mathrm{a}}$ & $111,283^{a}$ & $110,760^{a}$ & $66,583^{a}$ & $67,102^{a}$ & $66,843^{a}$ & $2.52^{\mathrm{a}}$ & $2.52^{\mathrm{a}}$ & $2.52^{\mathrm{a}}$ \\
\hline LCC & $100,481^{b c}$ & $100,556^{a b}$ & $100,519^{b}$ & $57,173^{a b}$ & $56,649 \mathrm{ab}$ & $56,911^{b}$ & $2.32 \mathrm{ab}$ & $2.30 \mathrm{abc}$ & $2.31^{\mathrm{b}}$ \\
\hline $\mathrm{SEm} \pm$ & 3170 & 3569 & 2387 & 3170 & 3569 & 2387 & 0.07 & 0.08 & 0.05 \\
\hline $\mathrm{CD}$ at $5 \%$ & 9251 & 10415 & 6785 & 9251 & 10415 & 6785 & 0.21 & 0.23 & 0.15 \\
\hline $\begin{array}{l}\text { Interaction effect } \\
\text { NS }\end{array}$ & NS & & & NS & & NS & NS & & NS \\
\hline
\end{tabular}

Different lowercase letters within the continuous columns are significantly different at $5 \%$ level of probability in Duncan's multiple ranges test (DMRT). Note: Conventional transplanting (TPR), direct-seeded rice (DSR) and drum seeded rice (DRR); farmer's practice (FP), the state recommended (SR), nutrient expert based (NE), Green seeker based (GS), leaf color chart (LCC) and non-significant (NS). 


\section{Discussion}

\subsection{Growth Parameter}

Weather and the rainfall pattern during the seeding and early establishment stage greatly influenced growth variation between DSR and TPR. Similar results were reported from the previous research $[23,47,48]$. The highest plant height was in NE treatment, followed by the state recommended dose and farmer field practice due to site-specific balanced fertilizer application as per demand in NE [49]. All treatments received more $\mathrm{N}$ than FP, and NE received maximum N. Probably, such expression of plant height is due to the $\mathrm{N}$ factor as $\mathrm{N}$ is known to increase plant height in rice. $\mathrm{NE}$ with more $\mathrm{N}$ might have resulted in elongation of internodes reflected in enhanced plant height [50].

The lower tiller number in DSR or DRR might be due to the fact that net photosynthate production was lower with these establishment methods than TPR [51,52]. Nitrogen is known to promote growth and tillering, and the treatments NE and GS received more N than other treatments. Because receiving more N, NE, and GS treatments produced more tillers in "Pratikhya" Kharif rice. The present study results conform to earlier research which mentioned more tillering due to higher leaf $\mathrm{N}$ content due to more $\mathrm{N}$ application $[53,54]$. In the first year (2017), rainfall affected the establishment of DSR adversely, but in the second year (2018), the rainfall pattern favored the initial establishment of rice crops and subsequent dry matter production. A similar type of observation was also reported in the previous experiment [55]. Therefore, DSR under favorable agroclimatic conditions might result in greater biomass production [56].

Site-specific N management, namely NE and GS, showed a positive impact in improving dry matter production in "Pratikhya" under Kharif condition rice as these treatments received more $\mathrm{N}$ than the remaining treatments. NE optimized fertilization management based on the $4 \mathrm{R}$ concept to harmonize crop nutrient requirement and application during the growing season [57]. Similarly, GS has also known as a reliable precision tool for $\mathrm{N}$ management and biomass production and superior to traditional practices [58]. Nutrient expert and Green Seeker-based nutrient management treatments received a higher dose of $\mathrm{N}$ and $\mathrm{N}$ has the most noticeable effect on LAI by increasing the number of tillers and leaf size [54]. The findings corroborate with earlier research [59], where differences in LAI due to the rice establishment method were observed [60-62].

\subsection{Yield and Yield Parameter}

Earlier findings [63] also noted higher panicles in rice with direct seeding and transplanting. TPR and DSR also produced a more significant number of effective tillers $\mathrm{m}^{-2}$. Enhancing effective tillers $\mathrm{m}^{-2}$ with these two treatments was probably due to proper partitioning of dry matter from source to sink. Earlier research also indicated the superiority of GS in the enhancement of effective tillers [40]. The impact of the establishment method on filled grains panicle ${ }^{-1}$ of rice was also proved by an earlier study [64]. The superior tiller growth with the photosynthates in functional leaves after heading in TPR may enhance the source for grain filling resulting in higher filled grain per panicle [65]. On the other hand, comparatively small sink capacity or insufficient source content and export might be the reason for low filled grain per panicle in DSR and DRR [66].

Earlier, several findings confirmed that rice grain and straw yield were influenced by the crop establishment method [67] and nitrogen management [68]. In our present study, the difference in grain yield of rice with DSR method between two years was probably due to climatic variation, i.e., higher rainfall in 2017 immediately after seeding and during the crop establishment period. In direct seeding, due to climatic factors and irregular stand establishment, rice yield was affected, as mentioned by earlier studies [69-73]. The yield variation between DSR and TPR is determined by climate and soil properties. Significant yield loss was reported in DSR due to climatic stress. DSR relative yield was $-25 \%$ when unbalanced climate stress occurred, whereas it was only $-7 \%$ without climate stress [74]. DSR could produce comparable yields to TPR but is more prone to yield losses due to inappropriate management practices, unsuitable soil properties, and climatic stresses. Wet 
seeding in puddled soil might be less suitable on soils prone to cracking and when there is a chance of rainfall after seeding unless fields are well-leveled and with good surface drainage systems [75]. Poor establishment in DSR can result from seed rotting and seedling damage if rain is immediate after sowing and continues for few days, which eventually negatively impacts growth and productivity $[76,77]$. Heavy rain, especially in heavier clay soils after sowing, tends to have poor distribution, germination, and emergence [78]. Although TPR and DSR were recorded statistically on par yield, numerically, TPR obtained a higher yield than DSR, which can be better explained due to the higher number of filled grain in TPR [79]. TPR resulted in significantly more filled grains panicle ${ }^{-1}$ than DSR and DRR due to $15 \%$ higher floret fertility in the TPR than DSR [75]. Grain yield was positively correlated with the yield attributing characters (panicle $\mathrm{m}^{-2}$ and number of grains panicle ${ }^{-1}$ ) of "Pratikhya" Kharif rice. In our present study, a higher correlation was found between the number of filled grains per panicle with grain yield $\left(r=0.84^{* *}\right.$, data was not displayed in this paper), and the regression equation indicated that $70 \%$ of the total variation in yield could be explained by the linear relation between the number of filled grains per panicle and grain yield.

In the current study, both GS and NE based N management expressed higher growth parameters, namely, dry matter production, LAI, number of tillers $\mathrm{m}^{-2}$ and yield attributes (particularly, panicles $\mathrm{m}^{-2}$ and number of grains panicle ${ }^{-1}$ ), and the impact of these characters was reflected in the productivity of rice. Regression study indicates that the number of panicle $\mathrm{m}^{-2}$ is correlated with yield, and $55 \%$ of the total variation in yield can be explained by the linear relation between the number of panicle $\mathrm{m}^{-2}$ and yield. Earlier research also evidenced GS and NE-based precision nutrient management in rice $[2,80,81]$. The number of filled grains per panicle was higher in GS, contributing significantly to grain yield $[40,49,80,82]$. By recommending a moderate amount of basal nitrogenous fertilizer at transplanting, enough $\mathrm{N}$ fertilizer in between active tillering and panicle initiation stage, and optical sensor-directed fertilizer $\mathrm{N}$ dose at panicle initiation stage, higher yield and nitrogen use efficiency can be achieved in transplanted rice [40]. Growth attributes and grain yield positively correlate with the canopy NDVI of rice [83]. GS considers leaf greenness and plant biomass compared to LCC, which determines nitrogenous fertilizer only based on leaf color, so GS may be considered a better $\mathrm{N}$ management tool even in not very well managed rice fields $[40,58]$. NE recorded a higher yield than SR and FP due to yield parameters, i.e., panicle $\mathrm{m}^{-2}$ [84] and filled grain per panicle [49]. The poor performance with DRR in the production of straw yield was probably due to inferior dry matter accumulation.TPR provided a uniform crop stand, and TPR superiority was observed from the earlier research $[85,86]$. Higher straw yields of NE and GS were probably due to more dry matter accumulation by the treatments. The results conform with other research $[87,88]$.

\subsection{Economics}

Higher return per rupee invested in DSR, compared to TPR and DRR, suggests that DSR is more cost-effective than other treatments. A similar observation was recorded by previous researchers [89]. A higher gross return was obtained from the transplanted method, but a higher net return and benefit-cost ratio were noted from the DSR method [90]. Most of the cost-saving in DSR came from avoiding nursery establishment and reduced labor in crop establishment as DSR required only $9 \%$ of the total cost, while it required $23 \%$ in TPR [91]. Despite the higher costs associated with an increased dose of N in NE, a higher income was obtained from yield gain than other treatments [2]. Previous research also confirmed as compared to FP, SSNM recorded an increase in yield by $7 \%$ and profitability by $12 \%$ [92]. NE is the better option over other nutrient management regarding yield and profit $[60,93]$. SSNM had a positive and significant effect on the economics of the "Pratikhya" Kharif rice variety. In our study, the highest return per rupee invested was in GS and NE due to higher yield and net return although higher production costs in these two treatments. There are vast possibilities to practice precision farming technologies in 
India using inexpensive and handy gadgets like LCCs and expensive devices like optical sensors [89].

\section{Conclusions}

In conclusion, the two years field study on crop establishment methods of "Pratikhya" Kharif rice indicated that DSR could obtain comparative growth, yield attributes, and yield with TPR in the Kharif rice system of the red and lateritic belt of West Bengal. Seed sowing in DSR and DRR should be done before the onset of monsoon for better establishment and a comparable yield with TPR. Poor establishment and growth attributes in drum seeding field management practices resulted in lower yield. The growth parameters, yield attributes (panicle $\mathrm{m}^{-2}$ and grains per panicle), and grain yield of "Pratikhya" Kharif rice variety were enhanced with site-specific nitrogen management like GS, NE, and LCC based $\mathrm{N}$ management compared to blanket application. Due to the lesser cost of cultivation and higher return per rupees invested, DSR proved to be more economically viable than TPR or DRR. GS and NE can be considered a more economical remunerative N management option in the experimental field of Birbhum. Based on present results, it could be concluded that DSR an alternative of transplanted rice and optimization of $\mathrm{N}$ application with sitespecific nutrient management like GS and NE as a better N management option in terms of growth, productivity, and profitability of rice production in the Kharif season under the red and lateritic belt of sub-tropical India. Further research is needed to work out the prescriptive $\mathrm{N}$ management to be followed at transplanting and active tillering before applying Green seeker-based fertilizer dose at the panicle initiation stage and to evaluate the $\mathrm{N}$ management and crop establishment methods under various agro-climatic zones and varieties.

Author Contributions: Conceptualization, S.M. (Samata Mohanta), M.B., G.C.M., T.S. and S.M. (Sagar Maitra); methodology, S.M. (Samata Mohanta), M.B., G.C.M., T.S. and S.M. (Sagar Maitra); software, S.M. (Samata Mohanta) and M.B.; validation, S.M. (Sagar Maitra), (Samata Mohanta), M.B. and G.C.M.; formal analysis, S.M. (Samata Mohanta) and M.B.; investigation, S.M. (Samata Mohanta), M.B. and G.C.M.; resources, M.B. and G.C.M.; data curation, S.M. and M.B.; writing-original draft preparation, S.M. (Samata Mohanta), M.B., G.C.M., T.S., S.M. (Sagar Maitra) and A.H.; writingreview and editing, I.A.I., E.S.D., A.O.A. and A.H.; visualization, S.M. (Samata Mohanta) and M.B.; supervision, M.B.; project administration, M.B. and G.C.M.; Funding, I.A.I., E.S.D., A.O.A. and A.H. All authors have read and agreed to the published version of the manuscript.

Funding: The current work was funded by Taif University Researchers Supporting Project number (TURSP-2020/120), Taif University, Taif, Saudi Arabia.

Institutional Review Board Statement: Not applicable.

Informed Consent Statement: Not applicable.

Data Availability Statement: Most of the recorded data are available in all Tables in the manuscript.

Acknowledgments: The authors extend their appreciation to Taif University for funding current work by Taif University Researchers Supporting Project number (TURSP-2020/120), Taif University, Taif, Saudi Arabia.

Conflicts of Interest: Authors would hereby like to declare that there is no conflict of interests.

\section{References}

1. Panda, D.; Nayak, A.K.; Mohanty, S. Nitrogen management in rice. Oryza 2019, 56, 125-135. [CrossRef]

2. Sapkota, T.B.; Jat, M.L.; Rana, D.S.; Khatri-Chhetri, A.; Jat, H.S.; Bijarniya, D.; Sutaliya, J.M.; Kumar, M.; Singh, L.K.; Jat, R.K.; et al. Crop nutrient management using Nutrient Expert improves yield, increases farmers' income and reduces greenhouse gas emissions. Sci. Rep. 2021, 11, 1564. [CrossRef] [PubMed]

3. Bijay, S.; Singh, Y. Management and Use Efficiency of Fertilizer Nitrogen in Production of Cereals in India; Issues and Strategies. J. Indian Nitrogen Manag. 2017, 10, 149-162.

4. Lassaletta, L.; Billen, G.; Grizzetti, B.; Anglade, J.; Garnier, J. 50 year trends in nitrogen use efficiency of world cropping systems: The relationship between yield and nitrogen input to cropland. Environ. Res. Lett. 2014, 9, 105011. [CrossRef] 
5. Ram, M.S.; Shankar, T.; Maitra, S.; Adhikary, R.; Swamy, G.V.V.S.N. Productivity, nutrient uptake and nutrient use efficiency of summer rice (Oryza sativa) as influenced by integrated nutrient management practices. Crop Res. 2020, 55, 65-72. [CrossRef]

6. GOI. Agricultural Statistics at a Glance 2018; Government of India Ministry of Agriculture and Farmers Welfare Department of Agriculture, Cooperation and Farmers Welfare, Directorate of Economics and Statistics, Government of India; GOI: New Delhi, India, 2018; pp. 87-89.

7. Shankar, T.; Banerjee, M.; Malik, G.C.; Dutta, S.; Maiti, D.; Maitra, S.; Alharby, H.; Bamagoos, A.; Hossain, A.; Ismail, I.A.; et al. The productivity and nutrient use efficiency of rice-rice-black gram cropping sequence are influenced by location specific nutrient management. Sustainability 2021, 13, 3222. [CrossRef]

8. Mohapatra, T.; Nayak, A.K.; Raja, R.; Shahid, M. Vision 2050; Central Rice Research Institute; Indian Council of Agricultural Research: Cuttack, India, 2013; p. 26.

9. Pathak, H.; Tripathi, R.; Jambhulkar, N.N.; Bisen, J.P.; Panda, B.B. Eco-Regional Rice Farming for Enhancing Productivity, Profitability and Sustainability; NRRI Research Bulletin No. 22; ICAR-National Rice Research Institute: Cuttack, India, $2020 ;$ p. 28.

10. FAOSTAT 2020. Available online: http://www.fao.org/faostat/en/\#data/RFN; http://www.fao.org/faostat/en/\#data/RL (accessed on 17 March 2020).

11. Ladha, J.K.; Pathak, H.; Krupnik, T.J.; Six, J.; Van, K.C. Effciency of fertilizer nitrogen in cereal production: Retrospect and prospects. Adv. Agron. 2005, 87, 85-156.

12. Adhikari, C.; Bronson, K.F.; Panaullah, G.M.; Regmi, A.P.; Saha, P.K.; Dobermann, A.; Olk, D.C.; Hobbs, P.R.; Pasuquin, E. On-farm $\mathrm{N}$ supply and $\mathrm{N}$ nutrition in the rice wheat system of Nepal and Bangladesh. Field Crop. Res. 1999, 64, 273-286. [CrossRef]

13. Surekha, K.; Kumar, M.R.; Nagendra, V.; Sailaja, N.; Satyanarayana, T. 4R Nitrogen management for sustainable rice production. Better Crop. South Asia 2016, 10, 16.

14. Alam, M.K.; Bell, R.W.; Hasanuzzaman, M.; Salahin, N.; Rashid, M.H.; Akter, N.; Akhter, S.; Islam, M.S.; Islam, S.; Naznin, S.; et al. Rice (Oryza sativa L.) Establishment techniques and their implications for soil properties, global warming potential mitigation and crop yields. Agronomy 2020, 10, 888. [CrossRef]

15. Bhatt, R.; Singh, P.; Hossain, A.; Timsina, J. Rice-wheat system in the northwest Indo-Gangetic plains of South Asia: Issues and technological interventions for increasing productivity and sustainability. Paddy Water Environ. 2021, 1-21. [CrossRef]

16. Farooq, M.; Siddique, K.H.M.; Rehman, H.; Aziz, T.; Lee, D.J.; Wahid, A. Rice direct seeding: Experiences, challenges and opportunities. Soil Tillage Res. 2011, 111, 87-98. [CrossRef]

17. Pathak, H.; Tewari, A.N.; Sankhyan, S.; Dubey, D.S.; Singh, M.U.; Jain, V.K.N.; Bhatia, A. Direct-seeded rice: Potential, performance and problems-A review. Curr. Adv. Agric. Sci. 2011, 3, 77-88.

18. De Datta, S.K. Technology development and the spread of direct seeded flooded rice in Southeast Asia. Exp. Agric. 1986, 22, 417-426. [CrossRef]

19. Pandey, S.; Velasco, L.E.; Suphanchaimat, N. Economics of direct seeding in northeast Thailand. In Direct Seeding: Research Strategies and Opportunities; Pandey, S., Mortimer, M., Wade, L., Tuong, T.P., Lopez, K., Hardy, B., Eds.; IRRI: Manila, Philippines, 2002; pp. 139-160.

20. Thet, K.; Ko, K.M.M.; Ngwe, K.; Min, T.D.; Win, K.K. Performance of Different Varieties in Direct Seeded Rice (Oryza sativa L.) as Affected by Different Sowing Methods. J. Agric. Res. 2019, 6, 65-71.

21. Bhatt, R.; Kukal, S.S. Direct Seeded Rice in South Asia. In Sustainable Agriculture Reviews; Lichtfouse, E., Ed.; Springer International Publishing: Cham, Switzerland, 2015; pp. 217-252. [CrossRef]

22. Ali, A.M.; Thind, H.S.; Singh, V.; Singh, B. A framework for refining nitrogen management in dry direct-seeded rice using GreenSeeker ${ }^{\mathrm{TM}}$ optical sensor. Comput. Electron. Agric. 2015, 110, 114-120. [CrossRef]

23. Ali, M.A.; Ladha, J.K.; Rickman, J.; Lales, J.S. Comparison of different methods of rice establishment and nitrogen management strategies for lowland rice. J. Crop Improv. 2006, 16, 173-189. [CrossRef]

24. Ahmed, S.; Latiful, B. Performance of Aus Rice in Different Tillage Systems and Crop Establishment Method in Southwest Bangladesh. J. Exp. Sci. 2018, 9, 05-08. [CrossRef]

25. Chen, S.; Ge, Q.; Chu, G.; Xu, C.; Yan, J.; Zhang, X.; Wang, D. Seasonal differences in the rice grain yield and nitrogen use efficiency response to seedling establishment methods in the Middle and Lower reaches of the Yangtze River in China. Field Crop. Res. 2017, 205, 157-169. [CrossRef]

26. Chauhan, B.S.; Awan, T.H.; Abugho, S.B.; Evengelista, G.; Sudhir, Y. Effect of crop establishment methods and weed control treatments on weed management, and rice yield. Field Crop. Res. 2015, 172, 72-84. [CrossRef]

27. Singh, B.; Sharma, R.K.; Kaur, J.; Jat, M.L.; Martin, K.L.; Singh, Y.; Singh, V.; Chandna, P.; Chaudhary, O.P.; Gupta, R.K.; et al. Assessment of the nitrogen management strategy using an optical sensor for irrigated wheat. Agron. Sustain. Dev. 2011, 31, 589-603. [CrossRef]

28. Ali, M.A. Development of an algorithm for optimizing nitrogen fertilization in wheat using GreenSeeker proximal optical sensor. Exp. Agric. 2020, 56, 688-698. [CrossRef]

29. Ramesh, C.; Pavithra, S. Fertiliser Use and Imbalance in India Analysis of States. Econ. Political Wkly. 2015, 50, 98-104.

30. Pathak, H. Nitrogen and climate change: Interactions, impacts, mitigation and adaptation. J. Indian Soc. Soil Sci. 2013, 60, 109-119.

31. Bouyoucos, G.J. Hydrometer method improved for making particle size analysis of soils. J. Agron. 1951, 54, 464-465. [CrossRef]

32. Jackson, M.L. Soil Chemical Analysis; Prentice Hall of India Pvt. Ltd.: New Delhi, India, 1973; pp. $183-193$. 
33. Walkley, A.; Black, I.A. An examination of the Degtjareff method for determining soil organic matter and a proposed modification of the chromic acid titration method. Soil Sci. 1934, 37, 29-38. [CrossRef]

34. Subbiah, B.V.; Asija, G.L. A rapid procedure for the determination of available nitrogen in soils. Curr. Sci. 1956, 25, 259-260.

35. Bray, R.H.; Kurtz, L.T. Determinations of total, organic and available forms of phosphorus in soils. Soil Sci. 1945, 59, 39-45. [CrossRef]

36. Hanway, J.J.; Heidel, H. Soil analyses methods as used in Iowa State College Soil Testing Laboratory. Iowa Agric. 1952, 57, 1-31.

37. Adhikari, B.; Bag, M.K.; Bhowmick, M.K.; Kundu, C. Status Paper on Rice in West Bengal; Hyderabad (India): Rice Knowledge Management Portal (RKMP). Directorate of Rice Research, Rajendranagar, Hyderabad 500030, India. 2011; pp. 1-47. Available online: http:/ / www.rkmp.co.in/sites/default/files/ris/rice-state-wise/Status\%20Paper\%20on\%20Rice \%20in \%20West \% 20Bengal.Pdf (accessed on 28 April 2021).

38. Pampolino, M.F.; Witt, C.; Pasuquin, J.M.; Johnston, A.; Fisher, M.J. Development approach and evaluation of the Nutrient Expert software for nutrient management in cereal crops. Comput. Electron. Agric. 2012, 88, 103-110. [CrossRef]

39. Ali, A.M.; Abou-Amer, I.; Ibrahim, S.M. Using GreenSeeker active optical sensor for optimizing maize nitrogen fertilization in calcareous soils of Egypt. Arch. Agron. Soil Sci. 2018, 64, 1083-1093. [CrossRef]

40. Singh, B.; Singh, V.; Purba, J.; Sharma, R.K.; Jat, M.L.; Singh, Y.; Thind, H.S.; Gupta, R.K.; Chaudhary, O.P.; Chandna, P.; et al. Site-specific fertilizer nitrogen management in irrigated transplanted rice (Oryza sativa) using an optical sensor. Precis. Agric. 2015, 16, 455-475. [CrossRef]

41. Xue, L.; Li, G.; Qin, X.; Yang, L.; Zhang, H. Topdressing nitrogen recommendation for early rice with an active sensor in South China. Precis. Agric. 2014, 15, 95-110. [CrossRef]

42. Nayak, A.K.; Mohanty, S.; Raja, R.; Shahid, M.; Lal, B.; Tripathi, R.; Bhattacharyya, P.; Panda, B.B.; Gautam, P.; Thilagam, V.K.; et al. Customized Leaf Colour Chart for Nitrogen Management in Rice for Different Ecologies. CRRI News Letter January-March. 2013, 34, 14. Available online: http:/ / www.crri.nic.in/CRRI_newsletter/crnljanmar13.pdf (accessed on 20 May 2021).

43. Roshanak, S.; Rahimmalek, M.; Goli, S.A.H. Evaluation of seven different drying treatments in respect to total flavonoid, phenolic, vitamin C content, chlorophyll, antioxidant activity and color of green tea (Camellia sinensis or C. assamica) leaves. J. Food Sci. Technol. 2016, 53, 721-729. [CrossRef] [PubMed]

44. Sestak, Z.; Catsky, J.; Jarvis, P.G. Plant Photosynthetic Production. Manual of Methods; Junk, W., Ed.; The Hague: The Netherlands, 1971; pp. 818-824.

45. Watson, D.J. The physiological basis of variation in yield. Adv. Agron. 1952, 4, 101-145.

46. Cochran, W.G.; Cox, G.M. Experimental Design; Asia Publishing House: Calcutta, India, 1977; pp. $142-181$.

47. Yogeswari, D.; Porpavai, S. Effect of crop establishment methods and irrigation scheduling on growth and yield of rice. Int. J. Chem. Stud. 2018, 6, 32-35.

48. Gill, J.S.; Walia, S.S.; Gill, R.S. Direct seeded rice: An alternative rice establishment technique in north-west India-A review. Int. J. Adv. Res. 2014, 2, 375-386.

49. Gupta, G.; Shrestha, A.; Shrestha, A.; Amagain, L.P. Evaluation of different nutrient management practice in yield and growth in rice in Morang district. Adv. Plants Agric. Res. 2016, 3, 187-191. [CrossRef]

50. Chou, J.T.; Wu, Z.; Jiang, T.H.; Liu, F.; Zhang, Z.J. Effects of nitrogen reduction at different growth stages on rice population production characteristics and preliminary analysis of nitrogen reduction strategies. J. Yangzhou Univ. 2020, 65, 52-58.

51. Moldenhauer, K.A.K.; Gibbons, J.H. Rice Morphology and Development. In Rice: Origin, History, Technology, and Production; Smith, C.W., Dilday, R.H., Eds.; John Wiley \& Sons, Inc.: Hoboken, NJ, USA, 2003; pp. 103-128.

52. Huang, M.; Zou, Y.; Jiang, P.; Xia, B.; Feng, Y.; Cheng, Z.; Mo, Y. Yield Component Differences between Direct-Seeded and Transplanted Super Hybrid Rice. Plant Prod. Sci. 2011, 14, 331-338. [CrossRef]

53. Zhong, X.; Peng, S.; Sanico, A.L.; Liu, H. Quantifying the interactive effect of leaf nitrogen and leaf area on tillering of rice. J. Plant Nutr. 2003, 26, 1203-1222. [CrossRef]

54. Fageria, N.K. Yield physiology of rice. J. Plant Nutr. 2007, 30, 843-879. [CrossRef]

55. Kumhar, B.L.; Chavan, V.G.; Rajemahadik, V.A.; Kanade, V.M.; Dhopavkar, R.V.; Tilekar, R.N. Effect of different rice establishment methods on growth, yield and different varieties during kharif season. Int. J. Plant Ani Environ. Sci. 2016, 6, 127-132.

56. Liu, H.; Hussain, S.; Zheng, M.; Peng, S.; Huang, J.; Cui, K.; Nie, L. Dry direct-seeded rice as an alternative to transplanted-flooded rice in Central China. Agron. Sustain. Dev. 2015, 35, 285-294. [CrossRef]

57. Wang, Y.; Li, C.; Li, Y.; Zhu, L.; Liu, S.; Yan, L.; Feng, G.; Gao, Q. Agronomic and environmental benefits of nutrient expert on maize and rice in Northeast China. Environ. Sci. Pollut. Res. 2020, 27, 28053-28065. [CrossRef] [PubMed]

58. Ali, A.M.; Thind, H.S.; Sharma, S.; Singh, V. Prediction of dry direct-seeded rice yields using chlorophyll meter, leaf color chart and GreenSeeker optical sensor in northwestern India. Field Crop. Res. 2014, 161, 11-15. [CrossRef]

59. Sharma, V.; Bali, A.S.; Kachroo, D. Effect of different establishment methods and sowing schedules on growth and yield of hybrid rice (Oryza sativa) and their after effects on succeeding wheat (Triticum aestivum) in rice-Wheat cropping system. Econ. Aff. 2016, 61, 487-493. [CrossRef]

60. Budhathoki, S.; Amgain, L.P.; Subedi, S.; Iqbal, M.; Nikee Shrestha, N.; Aryal, S. Assessing growth, productivity and profitability of drought tolerant rice using nutrient expert-Rice and other precision fertilizer management practices in Lamjung, Nepal. Acta Sci. Agric. 2018, 2, 153-158. [CrossRef] 
61. Kumar, T.; Singh, G.; Singh, R.A.; Shahi, A.K.; Kumar, M.; Rajput, S.K.S. Effect of site-specific nutrient management on productivity and profitability of rice in low land situation. Int. J. Chem. Stud. 2019, 7, 1963-1966.

62. Pateel, V.L.; Veeresh, H.; Narayana, K.R.; Gaddi, A.K.; Basavanneppa, M.A. Use of chlorophyll meter and optical sensors for nitrogen management in direct seeded rice. J. Farm Sci. 2017, 30, 365-369.

63. Alam, M.; Sarker, S.; Momin, M.A. Profitability of rice production using a drum seeder. J. Bangladesh Agril. Univ. 2007, 5, 135-144.

64. Ramesh, S.; Chandrasekaran, B. Evaluation of crop establishment methods and nitrogen management strategies on realizing yield potential of rice hybrid ADTRH 1. Asian J. Plant Sci. 2007, 6, 239-251. [CrossRef]

65. Zhu, D.; Zhang, H.; Guo, B.; Xu, K.; Dai, Q.; Wei, H.; Gao, H.; Hu, Y.; Cui, P.; Huo, Z. Effects of nitrogen level on yield and quality of japonica soft super rice. J. Integr. Agric. 2017, 16, 984-991. [CrossRef]

66. Yang, J.; Zhang, J. Crop management techniques to enhance harvest index in rice. J. Exp. Bot. 2010, 61, 3177-3189. [CrossRef]

67. Bhagavathi, M.S.; Baradhan, G.; Suresh Kumar, S.M.; Arivudainambi, S. Effect of different crop establishment methods on rice (Oryza sativa L.): A review. Plant Arch. 2020, 20, 3416-3422.

68. Bana, R.C.; Yadav, S.S.; Shivran, A.C.; Singh, P.; Kudi, V.K. Site-specific nutrient management for enhancing crop productivity. Int. Res. J. Pure Appl. Chem. 2020, 21, 17-25. [CrossRef]

69. Rickman, J.F.; Pyseth, M.; Bunna, S.; Sinath, P. Direct seeding of rice in Cambodia. In Increased Lowland Rice Production in the Mekong Region; Fukai, S., Basnayake, J., Eds.; ACIAR: Canberra, ACT, Australia, 2001; p. 101.

70. Lav, B.; Ladha, J.K.; Gupta, R.K.; Singh, S.; Tirol-Padre, A.; Saharawat, Y.S.; Gathala, M.; Pathak, H. Saving of water and labour in rice-wheat systems with no-tillage and direct seeding technologies. Agron. J. 2007, 99, 1288-1296.

71. Kaur, J.; Singh, A. Direct seeded rice: Prospects, problems/constraints and researchable issues in India. Curr. Agric. Res. J. 2017, 5, 13-32. [CrossRef]

72. Kumar, P.; Kumar, S.; Mouriya, A.K.; Kumar, V. Productivity and economics of direct seeded rice. Int. J. Sci. Environ. Technol. 2018, 7, 2033-2039.

73. Rashid, M.H.; Alam, M.M.; Khan, M.A.H.; Ladha, J.K. Productivity and resource use of direct-(drum)-seeded and transplanted rice in puddled soils in rice-rice and rice-wheat ecosystems. Field Crop. Res. 2009, 113, 274-281. [CrossRef]

74. Xu, L.; Li, X.; Wang, X.; Xiong, D.; Wang, F. Comparing the Grain Yields of Direct-Seeded and Transplanted Rice: A Meta-Analysis. Agronomy 2019, 9, 767. [CrossRef]

75. Yadav, S.; Evangelista, G.; Faronilo, J.; Humphreys, E.; Henry, A.; Fernandez, L. Establishment method effect on crop performance and water productivity of irrigated rice in the tropics. Field Crop. Res. 2014, 166, 112-127. [CrossRef]

76. Gopal, R.; Jat, R.K.; Malik, R.K.; Kumar, V.; Alam, M.M.; Jat, M.L.; Mazid, M.A.; Saharawat, Y.S.; McDonald, A.; Gupta, R. Direct Dry Seeded Rice Production Technology and Weed Management in Rice Based Systems; Technical Bulletin; International Maize and Wheat Improvement Center: New Delhi, India, 2010; p. 28.

77. Gupta, R.K.; Ladha, J.K.; Singh, S.; Singh, R.; Jat, M.L.; Saharawat, Y.; Singh, V.P.; Singh, S.S.; Singh, G.; Sah, G.; et al. Production Technology for Direct Seeded Rice; Rice-Wheat Consortium Technical Bulletin 8; Rice-Wheat Consortium for the Indo-Gangetic Plains; NASC: New Delhi, India, 2006; p. 16.

78. Bell, M.A.; Rickman, J.; Castro, J.E.C.; Actan, L.B.; McNamara, J. Precision land leveling for rice production in Asia. In Proceedings of the International Agricultural Engineering Conference; Salokhe, V.M., Jianxia, Z., Eds.; Asian Institute of Technology (AIT): Bangkok, Thailand, 1998; pp. 257-264.

79. Rahman, A.; Salam, M.A.; Kader, M.A. Effect of crop establishment methods on the yield of boro rice. J. Bangladesh Agric. Univ. 2019, 17, 521-525. [CrossRef]

80. Goudra, S.; Mudalagiriyappa, D.C.; Kalyana, K.N.; Murthy, P.K.; Kumar, M.P. Influence of precision nitrogen management through crop sensors on growth and yield of aerobic rice (Oryza sativa L.). J. Pharm. Phytochem. 2019, 8, $2409-2413$.

81. Ladha, J.K.; Jat, M.L.; Stirling, C.M.; Chakraborty, D.; Pradhan, P.; Krupnik, T.J.; Sapkota, T.B.; Pathak, H.; Rana, D.S.; Tesfaye, K.; et al. Achieving the sustainable development goals in agriculture: The crucial role of nitrogen in cereal-based systems. Adv. Agron. 2020, 163, 39-116. [CrossRef]

82. Kandel, S.; Shrestha, A.; Neupane, M.P. Assessing the growth and productivity of rice under different fertilizer management practices grown under SRI Production in Kavre, Midhill of Nepal. Ann. Rev. Res. 2018, 3, 555614.

83. Liu, X.; Ferguson, R.B.; Zheng, H.; Cao, Q.; Tian, Y.; Cao, W.; Zhu, Y. Using an Active-Optical Sensor to Develop an Optimal NDVI Dynamic Model for High-Yield Rice Production (Yangtze, China). Sensors 2017, 17, 672. [CrossRef] [PubMed]

84. Shrestha, S.; Amgain, L.; Subedi, R.; Shrestha, P.; Shahi, S. Productivity and Profitability Analysis of Old Aged Hybrid Rice Seedling Using Nutrient-Rice Expert and Other Precision Nutrient Management Practices at Lamjung, Nepal. Int. J. Appl. Sci. Biotechnol. 2018, 6, 232-237. [CrossRef]

85. Hossain, M.F.; Salam, M.A.; Uddin, M.R.; Pervez, Z.; Sarkar, M.A.R. A comparative study of direct seeding versus transplanting method on the yield of aus rice. J. Agron. 2002, 1, 86-88. [CrossRef]

86. Raj, S.K.; Jose, N.; Mathew, R.; Leenakumary, S. Influence of stand establishment techniques on yield and economics of rice cultivation in Kuttanad. Int. J. Sci. Res. Publ. 2013, 3, 1-6.

87. Seth, M.; Thakurand, D.R.; Manuja, S. Effect of tillage and site-specific nutrient management on productivity of rice-wheat cropping system. J. Crop Weed. 2019, 15, 115-119.

88. Krishnakumar, S.; Haefelem, S. Integrated nutrient management and LCC based nitrogen management on soil fertility and yield of rice (Oryza sativa L.). Sci. Res. Essays 2013, 8, 2059-2067. [CrossRef] 
89. Kumar, S.; Panwar, A.S.; Naresh, R.K.; Singh, P.; Mahajan, N.C.; Chowdhary, U.; Kumar, S.; Malik, M.; Meena, A.L.; Ghashal, P.C.; et al. Improving Rice-wheat cropping system through precision nitrogen management: A review. J. Pharma. Phytochem. 2018, 7, 1119-1128.

90. Kumar, A.; Jnanesha, A.C. Effect of Crop Establishment Methods on Growth Yield and Water Productivity of Rice. Int. J. Agric. Sci. 2017, 8, 40-45.

91. Devkota, K.P.; Khanda, C.M.; Beebout, S.J.; Mohapatra, B.K.; Singleton, G.R.; Puskur, R. Assessing alternative crop establishment methods with a sustainability lens in rice production systems of Eastern India. J. Clean. Prod. 2020, 244, 118835. [CrossRef]

92. Dobermann, A.; Witt, C.; Dawe, D.; Gines, G.C.; Nagarajan, R.; Satawathananont, S.; Son, T.T.; Tan, P.S.; Wang, G.H.; Chien, N.V.; et al. Site-specific nutrient management for intensive rice cropping systems in Asia. Field Crop. Res. 2002, 74, 37-66. [CrossRef]

93. Qureshi, A.; Singh, D.K.; Pandey, P.C.; Singh, V.P.; Raverkar, K.P. Site specific nutrient management approaches for enhancing productivity and profitability in rice and wheat under rice-wheat cropping system. Int. J. Agric. Sci. 2016, 8, $2838-2842$. 